\section{Erwin Neter Passes Away}

Prof. Erwin Neter, M.D., passed away unexpectedly on 2nd November 1983 at the age of 74 . This tribute is dedicated to one of the most prominent microbiologists and pediatricians who was actively involved in the field of infectious diseases.

Among his most recent honors, the microorganism Cedecea sp. 4 was renamed Cedecea neteri thereby placing Erwin Neter among the microbiologists whose names will never be forgotten. In addition to this great honor, he was also named Honorary Member of the American Society for Microbiology with the tribute that he was an "eminent scientist who had made a great contribution to microbiology"; of the 30,000 members of this organization, only about 50 individuals have been awarded this distinction. One of his most significant achievements was to be nominated Honorary Doctor of the University of Heidelberg ten years ago, and to be awarded the Federal Cross of Merit in 1979 , which is the highest civilian award the Federal Republic of Germany can bestow. Shortly before his death, he was also elected Chairman of the American Academy of Microbiology for a five-year term.

Erwin Neter once said: "My father gave me life twice. Once biologically. The second time was when he urged me to emigrate to the United Staates." This was absolutely true, because as a recent graduate, he did not enjoy the same protection as his famous Jewish teacher, the pediatrician Moro, who was able to remain in Heidelberg and in his home until his death in 1959 - in spite of tremendous adversity. Erwin Neter also lived two lives in another sense as well. His new life in the early 1950s brought out something unique in Erwin Neter. His roots lay just as much in his old life as in his new one; he lived in the one world as much as in the other and felt at home in both. On the one hand, he published important scientific papers in Buffalo, N.Y., while on the other, he worked together with colleagues from the MaxPlanck Institute in Freiburg or with $\emptyset$ rskov and Kaufmann from the Staten Serum Institute in Copenhagen. He was just as involved with pediatricians interested in infectious diseases as he was with West German microbiologists and, of course, a large number of American colleagues.

One was always tremendously impressed by the way in which life as a whole fascinated him - whether it be in a scientific or a cultural sense. Yet despite this intense involvement in life, he continually showed a child-like sense of humor - in the nicest sense of the word. Moreover, he always found time to help friends, indeed, in a way which I personally have never experienced before. I have no doubt whatsoever that he was aware of his personal achievements on the two continents, and I am sure that no one could ever have been happier than he was to receive recognition of this when he was awarded the "Großes Verdienstkreuz" by the Federal Republic of Germany in 1979. This was indeed a tremendous honor for a foreign scientist.

We all know that the work and the honors mentioned here represent only a small part of his professional life. His achievements in the field of science have been of particular importance for pediatrics, whether it be his contributions to the study of diarrhea or the serological correlation in UTI. He was also well known for his editorial talents in his work for Infection and Immunity. Everyone who knew Erwin Neter will agree that he was a most unique person with a wonderful aura. We experienced this many times in Munich when he gave lectures. His presence could always be felt when he chaired a meeting or when he sat with friends in a cosy restaurant in his birth town of Mannheim sipping on a glass of good red wine and lapsing into a very unmistakable Mannheim accent, humorously entertaining those around him.

Perhaps some people were jealous of him, but I am certain that he never had any enemies, because his bright character and extreme modesty had too much of an impact on all who knew him.

It would have been impossible for me to have been satisfied on this sad occasion with only a dry, factual account of Erwin Neter's achievements. Like so many of his good friends, I have a lot to thank him for in many respects. He will always remain in our hearts as one of our great contemporaries.

Walter Marget 